\title{
EDITORIAL
}

\section{El valor histórico de la celebración del 8 de Marzo como Día Internacional de las Mujeres}

\author{
ROSARIO RUIZ FRANCO \\ Universidad Carlos III de Madrid \\ orcid id: 0000-0001-7654-0239
}

doi: https://doi.org/10.20318/femeris.2018.4329

La conmemoración del 8 de marzo (8M), Día internacional de la Mujer, congrega a mujeres de diferentes países del mundo, con culturas, etnias, lenguas, religiones, ámbitos políticos, económicos y culturales muy diferentes entre ellas. Esa diversidad es uno de los valores en la celebración de esa fecha. Mujeres de muy distintas procedencias y muy diferentes entre ellas se unen para reivindicar mejoras en su situación jurídica, laboral, social, familiar o sexual, entre otras. Las desigualdades que sufren en sus respectivas sociedades patriarcales las unen y de una forma simbólica quieren hacerlas presentes ante la opinión pública, pues son conscientes de que en el largo caminar de su lucha y de sus conquistas todavía quedan asuntos por mejorar.

La celebración del 8 de marzo de 2018 ha tenido un significado y una proyección social y mediática muy importante en todo el mundo, si bien las movilizaciones que se han desarrollado en España han sido notorias por su poder de convocatoria y la rotundidad de sus reivindicaciones en aspectos laborales, salariales, jurídicos, sociales, y sexuales, por citar algunos. Como todos sabemos no es la primera vez que se celebra el 8M pero tal vez no todo el mundo sepa que su conmemoración hunde sus raíces en el contexto histórico de las reivindicaciones del movimiento feminista contemporáneo como un intento de mejorar la situación de las mujeres dentro del modelo patriarcal de relación entre los sexos. Hay distintas interpretaciones sobre los orígenes históricos del 8 de marzo, vinculados con movilizaciones de mujeres obreras o trágicos acontecimientos como el acaecido en la ciudad de New York en el año 1911 en donde se produjo un trágico incendio en una fábrica textil, y fallecieron más de un centenar de trabajadoras. La interpretación más plausible sobre el origen histórico del 8M es la que se enmarca en el movimiento socialista de reivindicación de derechos hacia las mujeres. A comienzos del siglo XX la política 
comunista Clara Zetkin en la II Conferencia Internacional de Mujeres Socialistas, celebrada en Copenhague en el año 1910, propuso la celebración de un Día Internacional de las Mujeres con el objetivo de promover la igualdad de derechos entre hombres y mujeres en el mundo. El convulso periodo histórico que vivió el mundo desde 1914 hasta 1945 con el desarrollo de las dos guerras mundiales, la crisis económica de 1929, y la emergencia de los fascismos hizo que esa conmemoración quedara difuminada. Con la creación de las Naciones Unidas (ONU) la reivindicación de los derechos de las mujeres recibió un importante apoyo en el ámbito internacional como queda reflejado en su Declaración de Derechos Humanos aprobada en el año 1948, y en donde Eleanor Roosevelt tuvo un papel destacado en su elaboración. Sin embargo no sería hasta que en el año 1975, declarado como Año Internacional de la Mujer, se impulsaron mejoras en la situación de las mujeres de forma coordinada y bajo el paraguas del referido organismo internacional. A partir de esa fecha Naciones Unidas, y con una clara intención simbólica, comenzó a celebrar el 8 de Marzo como Día Internacional de las Mujeres, y ha llevado a cabo una importante actividad, como queda reflejado en las iniciativas llevadas a cabo por ONU Mujeres y en la actualidad con los objetivos establecidos en la denominada Agenda 2030, a través de los que se busca fomentar la igualdad de género y el empoderamiento de las mujeres y las niñas.

La celebración del 8M también nos debe servir para recordar a quienes, con anterioridad a nuestro presente histórico, han contribuido con su trabajo y su esfuerzo en la lucha por la igualdad entre hombres y mujeres. De algunas conocemos sus nombres, las pioneras como Clara Zetkin, Alejandra Kollontai, Rosa Luxemburgo, y desde el ámbito español, por citar algunas: Concepción Arenal, Clara Campoamor, Victoria Kent, Margarita Nelken, Virginia González, María Cambrils o Teresa Claramunt. Pero no de todas sabemos sus nombres o su trabajo en favor de la igualdad entre hombres y mujeres, por lo que es importante rescatar sus nombres y sacar los hechos históricos que protagonizaron del olvido. De ahí que sea muy importante conocer las genealogías femeninas para valorar la herencia recibida y poder legarla. En la conmemoración de acontecimientos como el $8 \mathrm{M}$ es especialmente significativo este aspecto. El camino recorrido, los avances logrados, conviene recordarlo como un ejercicio pedagógico para saber de dónde venimos y quienes nos precedieron en la defensa de la igualdad de género, pero también para afrontar con decisión y confianza los retos que presenta el futuro como ha quedado evidenciado muy recientemente en el último $8 \mathrm{M}$.

La conmemoración del 8M del año 2018 ha sido especialmente significativa por la convocatoria de una huelga y la realización de una serie de movilizaciones en más de 150 países en todo el mundo con un importante seguimiento y participación, lo que evidencia la necesidad de impulsar todavía, tras más de un siglo de reivindicaciones, mejoras en la situación de las mujeres en muy diferentes ámbitos. Bajo el lema "libres, vivas, feministas, combativas y rebeldes", colectivos feministas, organizaciones sindicales, algunos partidos políticos, ONGS, entre otros, convocaron y secundaron una huelga inédita. Su originalidad radica en que no sólo ha sido un paro en la actividad profesional sino también el cese de actividades en el ámbito doméstico, en donde las mujeres desarrollan una labor silenciosa y sin apenas reconocimiento, así como una huelga de consumo como una forma de denunciar 
que los cuerpos de las mujeres no son un reclamo para incentivar el mismo, en el que las mismas se convierten en un reclamo muchas veces debido a las exigencias que se imponen. Toda esta movilización intentaba evidenciar que "si las mujeres paran, se para el mundo".

Esta movilización del año 2018 ha supuesto un paso muy importante no solo en las reivindicaciones feministas sino también en la toma de conciencia por parte de la sociedad. Asuntos como conciliación, brecha salarial, o techo de cristal, se discuten en la calle, en el ámbito familiar y profesional. El feminismo y sus reivindicaciones han recuperado un espacio y una consideración mayor en el ámbito público. Pero no nos conformemos ni demos cabida a la autocomplacencia ya que hay todavía un largo camino por recorrer, pues sabemos que las conquistas legales alcanzadas no siempre se corresponden con la realidad social, la crisis económica ha dañado especialmente el tejido profesional femenino, existen discriminaciones salariales manifiestas, queda mucho por avanzar en una verdadera política de conciliación que permita a las mujeres no verse en la tesitura de elegir entre familia o trayectoria profesional, y como evidencian los datos la violencia contra las mujeres es una auténtica lacra social. Además en muchos países del mundo nos encontramos con situaciones extremas como los matrimonios infantiles, la ablación, la trata con fines sexuales o el analfabetismo femenino, en una larga lista de injusticias. Las demandas feministas están ahora necesitadas de una atención efectiva y continuada en las agendas oficiales de los diferentes gobiernos nacionales, instituciones y organismos internacionales. Confiemos en que si el siglo XX fue el siglo de las mujeres, el siglo XXI lo sea de la igualdad efectiva de mujeres y hombres. El legado histórico de las mujeres que a lo largo de la historia, y muy especialmente en los albores del siglo XX, lucharon por la igualdad entre los sexos no debe quedar en el olvido, sino que debe servir de ejemplo para las nuevas generaciones de mujeres que luchan por una sociedad más justa e igualitaria. Quienes tenemos la fortuna de desempeñar tareas docentes tenemos un importante papel en esta misión. Que no se nos olvide, recordando a John Stuart Mill, que el progreso de las naciones se mide por el progreso de sus mujeres. 